\title{
Rituals of Rule in the Administered Community: The Javanese Slametan Reconsidered
}

\author{
JAN NEWBERRY \\ University of Lethbridge
}

\begin{abstract}
Ethnographic work in an urban kampung in central Java reveals this community form to be both an administrative rationality and a set of locally meaningful social relations. The continued restatement of the relevance of community through the Javanese ritual meal known as the slametan and women's roles in these rituals of commensality are the focus of this consideration. State sponsorship of housewives as community welfare workers extends the long arch of kampung community formation as the ground for the dispersion of rituals of rule into the lives of Indonesian citizens as well as working-class recuperation through rituals of community. State formation conceived as process draws attention to everyday kampung culture as the matrix for reproduction of both rule and working class neighbourhoods, and provides a perspective on the state that is resolutely low, attuned to both the realities of institutional structure and the repertoires and routines of everyday practise.
\end{abstract}

Late in the afternoon, in that hour when the sun has finally relented its hold over Java, the first breath of evening coolness begins to circulate through the densely packed urban neighbourhoods known as kampung. This late afternoon period called sore is marked by the requisite second bathing of the day, informal socializing by neighbours in front of their houses, raucous shouting by children, front-step lounging, and volleyball or soccer playing in the few empty spaces between houses. The rhythm of the day changes at this time, both slowing because the work day is done but quickening too because it is the time when neighbourhood business, both formal and informal, is conducted. This time of the day is often punctuated by a meeting of one kind or another. For me, because of my fieldwork on Javanese housewives, most often these were meetings of the oo26-749X/o6/\$7.50+\$0.10 
national housewives association (Support for the Prosperous Family, Pembinaan Kesejahateraan Keluarga, PKK). ${ }^{1}$

In 1993, after almost a year of living in a kampung in the central Javanese town of Yogyakarta, I had attended dozens of local meetings of neighbourhood women. In fact, it seemed that it was a rare day when there wasn't a group of adult, married women meeting in some kampung house to see to the everyday management of their neighbourhood as dictated by government administration. For meetings of the national housewives organization, women met in small groups to discuss neighbourhood sanitation, who would host the monthly baby weighing, the new elder care program, or the admonitions to follow the new motorcycle helmet law. Meetings of the local residential block associations, or section system, were also frequent, whether meetings of the smaller RT (Rukun Tetangga, Harmonious Neighbours) of approximately 10-1 2 contiguous households or the larger RW (Rukun Warga, Harmonious Citizens) consisting of six RT groups. Unlike PKK, these neighbourhood residential groupings were managed by both men and women who volunteered or were popularly selected but unpaid. Business here might include decorations for national independence day celebrations, or community maintenance of local streets, or yet another directive from the paid civil service that began directly above the RW section.

These meetings to conduct the routine management and administration of local community were part of the daily cycle of kampung life. Repeatedly organized as administrative units, these neighbourhood groups appear to represent state instrumentalities on the one hand, and yet on the other, they are manifestations of local patterns of exchange and support. Their constant reiteration at afternoon meetings, whose rhythm was interwoven with the rhythm of kampung life, presents a question about the limits of state rule and the beginnings of acts of neighbourliness, as I found out one afternoon at a PKK meeting held near the end of the month of fasting for Ramadan.

Typically, the meetings of the very smallest grouping of PKK in my corner of the kampung were short and centred largely on who would be taking home the pot from the monthly credit lottery (arisan). ${ }^{2}$ If

\footnotetext{
1 This work is based on several periods of ethnographic fieldwork, beginning with an initial research period in 1992-93. Subsequent fieldwork was done in 1998, 200o, 2002, and 2004.

${ }^{2}$ Arisan refers to the rotating credit lottery found throughout Indonesia (as well as other parts of the world) in association with almost any formal organization. At each
} 
there were announcements from the government to hear or duties to see to such as organizing hospital visits, this business was conducted with some dispatch. The ten or so women who attended routinely would conduct their business mixed with bawdy remarks and parodies of formal Javanese (Jv.) speech conventions. This was the style of PKK meeting favoured in my part of the kampung. Just one RT section over, the meetings were taken more seriously: a formal agenda was followed, the national language (Bahasa Indonesia, Ind.) was used, and food was always served. My near neighbours seemed to prize short meetings and worry little about conventions, although PKK meetings always seemed to me an odd mixture of the formal structure and language of government administration with the informal intimacy of close neighbours.

This neighbourhood, located near the centre of Yogyakarta, one of the central court cities of Java, had a large Catholic population due in part to the Catholic Church located just outside the entrance. This situation was perhaps surprising given the conventional description of Indonesia as 90 percent Muslim. There was certainly a majority of Muslims living on the narrow streets and alleys of this kampung, which housed the teachers, low-level civil servants, labourers, and the unemployed and under-employed characteristic of these working class neighbourhoods, whose residents were neither desperately poor nor solidly middle class. Still, the Catholic minority was large and noticeable. Given the clear Catholic majority among my near neighbours, I was astonished when the decision was made at this particular PKK meeting at the end of Ramadan-after the official announcements and business of the PKK section were completedthat we should now ask forgiveness of one another. Surprised and caught off-guard, I joined my Catholic neighbours as they stood up, arranged themselves in two concentric circles, and then walked in these two wheels from person to person, shaking hands and muttering "minta ma'af lahir batin" or 'I ask forgiveness body and soul'.

This asking for forgiveness at the end of Ramadan is traditional for Javanese Muslims, who typically complete this ritual by visiting the houses of kin and close neighbours, bearing food, and apologizing body and soul for any indiscretions, slights, or misunderstandings that

meeting, members contribute a fixed amount, and each in turn receives the entire collected amount during the course of the arisan's run (several, weeks, months, or as long as it takes). Although identified here as a credit lottery, the arisan is just as easily described as a savings association. 
might have occurred during the past year. The formulaic request for forgiveness is a standard part of many Javanese events and rituals; yet, this particular instance was clearly associated with Muslim practice, coming as it did at the end of Ramadan. As it happens, it was also a part of the routine practice of community. That is, these local housewives decided to dispense with the complications of individual rounds to neighbours' houses and accomplish this practice of community exchange within the structure of a government-sponsored PKK meeting. This abbreviated ritual of apology might be understood as yet another example of Javanese tolerance for religious difference. After all, these were Catholics performing what many would see as an Islamic practise. It might just as easily be understood as an example of Javanese syncretism in its apparent mixing of forms. Yet, this incident suggests not only the investiture of local community practice with the ideology of the dominant religion, but more significantly here, it represents the simultaneous investiture of governance with local cultural practices of community support and exchange, and importantly, those effected through the work of women.

How to understand what happened at the meeting that day? It would be possible to approach this as an example of governmentality, to see the context for this ritual of apology between neighbours as an extension of the rationality of state management, a particular knowledge practise whose dispersion to local houses aids in producing modernizing, self-regulating, and moral communities (see Burchell, Gordon and Miller 1991; Dean 1999; Foucault 1979; Lemke 2001; Mitchell 1999; Rose and Miller 1992; cf. Curtis 1995). Or, it might be useful to consider the role of administration and bureaucratic repertoires and routines in shaping local community interactions (Gupta 1995; Herzfeld 1992). Or, this neighbourhood meeting might be understood as an example of the ongoing formation of the state, that fractious historical and cultural project of domination that implies both the hegemony and class struggle that underlie the mask of "politically organized subjection" known as the "state" (Abrams 1988; see also Joseph and Nugent 1994; Corrigan and Sayer 1985; Day 2002). Clearly what transpired indicates the continued relevance of considering state rule and its intersection with local practise. Yet, there are other entailments as well. This moment might be understood to illustrate the lack of any civil society in these working class urban neighbourhoods, another illustration of the limits of the historically particular form of social and political organization associated with the modern, liberal democratic nation-state in Europe (Cohen and 
Arato 1992; Comaroff and Comaroff 1999; Ericksen 2001; cf. Tournquist 2002). That the meeting took place within a "private" home suggests that these neighbourhood meetings challenge the ambiguous boundary between government administration and the most intimate space of the family. The ritual of apology itself might be considered as an example of the performance of the state and the discursive means by which state rule is extended through the literal performance of power inside people's homes (Geertz 1980; Goldstein 2004; Gupta 1995).

All of these aspects were present in the moment when these neighbourhood women decided to use the state-sponsored national housewives organization, PKK, to accomplish the neighbourly task of apology. But I choose here a slightly different approach, through the back door one might say, to gain a perspective on the constitution of rule from within the houses of a working class community. The shaping of the domestic in the rise of the liberal nation-state in Europe is not a new approach to the accomplishment of rule and the sites resistance that arise as a consequence (Boris and Bardalgio 1983; Davidoff and Hall 1987; Donzelot 1979; Engels 1942; Harrison and Mort 1980; Pateman 1988; Scott and Tilly 1975). Yet, as we continue to bring the state back in, again and again (Curtis 1995; Day 2002; Evans, Rueschemeyer, and Skocpol 1985; Hansen and Stepputat 2001; Jessop 2001; Migdal 2001; Steinmetz 1999), the role of the domestic community in the making of state rule has not always been part of that reconsideration. A focus on kampung culture and the ritual work of women in households is used here to illustrate the ongoing and cumulative process of state formation-conceived as a historical and social process - always almost accomplished, virtual—rather than as a political accomplishment grounded in fixed institutions. An emphasis on the mutual constitution of community and state combines attention to making do by working class citizens at the borders of formal and informal labour with the making of common sense within a local culture of mutual support and exchange. The ongoing formation of state rule necessarily draws attention to everyday kampung culture which provides the matrix for both the reproduction of rule and the reproduction of working class neighbourhoods. Remarkably, despite dramatic changes in Indonesia's political make-up, elements of this state formation continue, perhaps explaining some of the stability that persists despite the changes.

In the following, a consideration of kampung community suggests that the community itself serves as an administrative form or 
rationality as well as a set of locally meaningful social relations that are in practise on a daily basis. The sharper focus here is on the role of women in the rituals of administered culture that help sustain these meanings of community, a perspective on the state that is resolutely low, attuned to both the realities of institutional structure and the repertoires and routines of everyday practise, but not ending there. A consideration of the Javanese ritual meal known as the slametan as the continued restatement of the relevance of community and the reliance on women's invisible work in these rituals of commensality expands this analysis. Finally, the state-sponsorship of housewives as community welfare workers is described to show how the long arch of kampung community formation (Williams 1961; Corrigan and Sayer 1985) has provided the ground for the dispersion of rituals of rule into the everyday lives of Indonesian citizens as well as the site for working-class recuperation through rituals of community.

A central question here will be the effect of administered culture on local practises of community. Does the reach of state rule through community management suggest the end of culture as an active process of making sense whose direction is not fixed but fungible? Do the administered mass organizations (Kasza 1995) used across various states represent the burial shroud of Javanese culture (Pemberton 1994) or forms whose realization is sensitive both to bureaucratic management as well as the interests of neighbours managing their burdens? And ultimately, do current analyses of the state allow us to answer these questions? Despite recent attention to the role of culture in understanding state rule (Day 2002; Gupta 1995; Migdal 2001; Steinmetz 1999), the gaps in governance locally remain unexamined for the most part, and the view of the state from inside houses and communities remains unexplored.

\section{Kampung Community as a Structure of Feeling}

Popular culture in Java is kampung culture in many ways. The term kampung in Indonesia has been used to refer to port city ethnic enclaves, royal guild areas, and rural village settlements, but in common usage now, kampung refers to urban neighbourhoods with high population density and low socioeconomic status (Guinness 1986, 1991; J. Sullivan 1980, 1986, 1992). In fact, kampung have two aspects, an inward face and an outward one. From the inside, kampung resonate with ideas of warm, supportive home community. From the 
outside, they are often seen as parochial, closed, and slum-like. Defined spatially in many respects, the boundaries of kampung have been re-inscribed in official administrative units, and just as often, by a kind of popular cognitive mapping of these dense neighbourhoods through their use historically and practically. One conception of the Javanese kampung has been as the settlement of wong cilik (Jv., little people) who live not at street-side but behind main streets along crowded alleyways or gang. During the colonial era, such invisible neighbourhoods would support the large houses of the Dutch that lined main city streets. The support function of these reserves of poor and lower class people was also evident in their crowding around royal court areas of the interior as well as their role in ethnically segregated trading cities along the coast.

Today, the inhabitants of kampung may range from wealthy to poor, but the majority are informal sector workers, a significant number working at or near home. More recent descriptions of class in Indonesia suggest the continuing invisibility of the majority of kampung residents. Robison (1996:88) describes a segment of the middle class as populist, and as including "the sprawling mass of clerks, teachers and lower-level civil servants." Although many of the kampung folk I worked with correspond to Robison's description, many more were poorer people, working in a mix of informal and service sector jobs. While not always the poorest in Indonesia's urban centres, kampung dwellers often lie at the boundaries of the formal and informal economies, in some cases resembling Marx's lumpenproletariat of prostitutes, beggars, and street performers, and at others, the labourers and home workers of early phases of industrialization, or ironically, the labour associated with the end of national industrial organization in late capitalism. ${ }^{3}$ In the neighbourhood where my work has been centred, occupations ranged from market seller to puppet-maker, masseuse, seamstress, nurse, fibreglass statute maker, prostitute, bank clerk, teacher, small food stall owner, maker of traditional health tonics, day labourer, and house-based piece-work subcontractor.

${ }^{3}$ The mix of informal sector work, subcontracted piece work, house-based smallscale industry, and semi-legal and illegal work that are often found in kampung resemble the early phases of industrialisation in England, and ironically, this same mix of economic activities seems ideally suited to a new era of globalisation and flexible accumulation (Harvey 1990). 
I use the term working class here quite deliberately, despite what seems its awkward fit with Indonesia. In its usage here, the socially conservative connotations of "working class" serve to mark this class fragment as distinct from the very poor and any putative middle class (Robison 1996; Hadiz 1997; Robison 1996; Shiraishi 2004). The lack of a true land-owing middle class or bourgeoisie is characteristic of Indonesia and many other parts of Southeast Asia. Elsewhere, I develop an argument about the usefulness of the kampung as a social and spatial container for a reserve army of labour (Newberry 1997, in press 2005). The kampung is suggested to house and support the chronically unemployed and underemployed in an economy that historically has had a labour surplus due to population growth and lack of effective industrial development. The use of the term working class here points our attention to the segment of the Javanese (and Indonesian) population that absorbs, supports, reproduces, and to some extent conceals the surplus labour that effectively keeps wages low and labour docile-key components of Indonesia's comparative economic advantage in the past and even now (Robison 1986; Wolf 1992). While it might be suggested that lumpenproletariat does indeed serve as a better description here, this would overlook rising incomes in these enclaves, but even more significantly, the cash and wages earned by women and men in formal waged employment as well as informal sector and part-time work. Just as importantly, it would overlook the official sanction of women's informal labour by the government through PKK. ${ }^{4}$

The use of a class analysis for understanding kampung culture must be further situated here, where class position results less from any specific articulation of forces and means of production than from a social formation in relation to and as against others. This character of "in terms of" other apparent classes of people is in many ways the basis for the current reproduction of the kampung as a distinct social formation. Ultimately, kampung are both the spatial expression of a process of low-cost social reproduction and labour absorption as well as the sentimental and moral expression of a particular way of life.

\footnotetext{
${ }^{4}$ Training and small loans are available to women through PKK to support home industries such as sewing and craft production. Moreover, the programs and literature of PKK are explicitly aimed at encouraging tambahan suami, or adding to the husband's income, although significantly in economic activities that are informal, low-waged, and low-skilled.
} 
Significantly, they are also the result of a history of administration of poor people in both rural and urban areas.

In their historical development, kampung have been represented as the official recognition of the authentic peasant village, autonomous, egalitarian and cooperative. They have likewise been understood as the manifestation of a rational division of labour produced by royal administration, as well as in the administration of both rural and urban areas during the Japanese occupation in WWII, during post-war nationalist organizing, and during the technocratic, modernizing New Order regime of Indonesia's second president, Suharto, from 1967 to 1998. That is, beyond the occupational and ethnic segregation that has characterized kampung at various points and beyond their expression of a particular class position, the administrative reality of kampung as units has been re-stated across regimes since at least the era of Dutch colonialism. The presumption of small groups of contiguous households, cooperating in the management of their own affairs, sharing as equals, and spreading burdens across their members has been a powerful image of use to various state administrations. Despite challenges to the reality of this primordialist image, the cooperative community continues to be enshrined not only in bureaucratic thinking but also in the local kampung practise.

The colonial state, for example, solidified and extended a particular view of the peasant village that would come to be applied to kampung neighbourhoods. The egalitarian, cooperative peasant community on Java was a part of the colonial imagination in the Indies (Breman 1980, 1988; Goh 1998; Rigg 1994), just as has been suggested for India (see Dumont 1966; Kemp 1988), and for Africa (Mamdani 1996; Mitchell 1988). That is, not only its presumed spatial contiguity and social integration but also the romantic spirit of cooperation were part of a larger colonial project of control and administration rather than any indigenous "tradition" alone. This vision of the rural village as a "small republic" that is autonomous and self-sustaining is longstanding for Java. This depiction of the distant state and the autonomous village continues an orientalism evident in scholarship from Marx's Asiatic mode of production to Geertz's shared poverty. ${ }^{5}$

${ }^{5}$ Day's analysis (2002) of how the state in Southeast Asia has been studied before and after the advent of the modern state in northwest Europe suggests the power of interpretative frameworks based on European models in shaping views of political power in other parts of the world. Colonial ethnology was often complicit in the 
Mamdani (1996), in his treatment of the postcolonial state in Africa, has noted the relevance of the ideal of tradition and custom taken to describe rural areas in contrast to urban spaces. He relates this difference to that in administration, that is, to the difference between direct rule based on the language of universal civil rights and indirect rule based on the language of tradition and customary culture specific to villages. These two approaches to rule by colonial states in Africa produced a bifurcated state and a decentralized despotism, according to Mamdani. What proves so interesting in the case of Java is how the idea of a traditional, customary village culture was transposed to the administration of urban neighbourhoods as well. In terms of Mamdani's analysis, the use of a model of indirect rule, here in both city and countryside, relates to the continued deferral of civil rights as well as to the capture of popular movements for use by state administration (Mamdani 1996).

In Java, during the period leading up to independence, social activists promoted a view of grassroots socialism that also was based on a vision of the egalitarian, cooperative rural community (Antlov 1995; Schulte Nordholt 1987). The Village Social Institution (Lembaga Sosial Desa) was developed at this time and later adopted and adapted by the new nationalist, modernizing Indonesian state to organize rural communities. The incorporation of this apparently "non-governmental" form for the sake of state-level governance of local communities coincided in large measure with a similar cooptation of a vibrant Independence-era women's movement devoted to aiding poor rural women (Suryakusma 1991, 1996; Wieringa 1988) by the programs of PKK. Ultimately, the Village Social Institution (LSD) became the state-organized Institute for the Resilience of Rural Society (Lembaga Ketahanan Masyarakat Desa; LKMD), a governmental arm aimed at development that emerged in 1980 during Suharto's New Order regime. The LKMD was extended to urban areas as well, and its structure would eventually incorporate the national housewives organization, PKK, under its organizational umbrella, as Suharto's 31 year rule placed development and modernization at the centre of its policies and practises.

Dutch colonial uses of community to organize poor rural people and Independence-era mobilization of grassroots rural communities were not the only precedents to the use of the small face-to-face community 
as an administrative unit. Japanese war-time administration is perhaps the clearest precedent for the RT/RW system (Benda et al. 1965; Kasza 1995; J. Sullivan 1992). Residential blocks headed by selected local men were used during Japanese wartime occupation to count and control the population in both rural and urban areas. The use of neighbourhood groups in Japan has been based on a notion of local consensus and cooperation between people living close by in the management of their own communities (Garon 1997; Bestor 1989), and its extension to Java was yet another administrative statement about the relevance of small community for local management. Ultimately, for Java, the shell of community governance and its populist local manifestation articulated with a larger governmental structure has been a characteristic of government regulation of poor people for some time. This articulation, as it happens, also reinforces the mutual but opposed aspects of inside and outside that continue in kampung life.

The residential block associations or neighbourhood section system was and is used by the government both to deliver social welfare inputs, such as money and information about education and health, and to organize local citizens to provide the labour and money for community projects. To this day, the Pak RT or Father RT and RW are still the first connection with official governance for most urban dwellers of the lower middle class and below. If papers must be filed or aid sought, it is to these locally selected men that residents turn. In matters of larger concern, it is still here that local residents begin their interaction with the government. The Pak RT is responsible also for the general welfare of the neighbourhood and area. If there are troubles with neighbours, it is the Pak RT who intercedes. If a neighbour has fallen on hard times, it is the RT who directs aid to them. In many ways, the system of local community governance, whatever its origins, has become the form of governmentality most basic to the emergence of state rule in Indonesia across regimes. Despite the dramatic political changes and plans to devolve more autonomy to local areas, the RT/RW system persists.

During one recent visit to the kampung in 2002, I visited with the Father and Mother RT of the neighbourhood section where I used to live. They lamented to me that all the changes associated with Reformasi (the post-1997 era associated with democratization and the end of Suharto's authoritarian regime) and otonomi daerah (regional autonomy) had occurred at the top. The poor people at the bottom still bore the brunt of local administration in their view, and 
in fact, they reported that they had been told by the higher levels of the civil service not to hold local elections for a time, until the situation stabilized. Although strikingly democratic in appearance to outsiders, the neighbourhood section system was held in stasis will "democratization" took place at the provincial and national levels. This continued burden was a hardship for the Pak and Ibu RT in my neighbourhood, who struggled to keep all the competing factions of the neighbourhood happy.

Struck by the stability and endurance of this community form even in a period of social upheaval, I searched through some of the new laws enacted since Suharto relinquished power. In Presidential Decree Number 49, year 2001, the basic form of RT/RW organization is reiterated although the decree consistently uses the phrase atau sebutan lain, "some other designation," after each use of the term RT or RW. In other words, the decree outlines again the usefulness of these small local groupings to, for example, memelihara kerukunan hidup warga or protect the harmonious life of citizens in the case of the RT or SOME OTHER DESIGNATION, or to menggerakkan swadaya gotong royong dan partisipasi masyarakat di wilayahnya, to motivate the innate self-supporting sense of mutual self-help and participation of the citizenry in the case of the RW or SOME OTHER DESIGNATION. In a fascinating reversal, the legislation suggests that this will require the end of LKMD as it currently exists because it is no longer appropriate to the spirit of regional autonomy, and for this reason it must return to an organization appropriate to the needs of the local-level of governance. ${ }^{6}$

What is interesting here, given the history of the replacement of the autonomous organization of the Village Social Institution (or LSD) with the government-sponsored Institute for the Resilience of Rural Society (LKMD), is the call for a return to its original intent as a vehicle for expressing local needs and requirements. This latest extension of the community form as a form of rule is based-yet again-on the idea of returning to the true roots of community, even as it works to secure community resources for state purposes-yet again. The decree makes specific reference to the social and cultural needs and conditions of different regions, and yet, the small local community organization is maintained. This reiteration, or re-"state"ment, of the need for these

\footnotetext{
${ }^{6}$ See Antlov (2003) for a consideration of the changes in democratic politics evident in village councils and citizens' forums after Reformasi and decentralisation.
} 
small local groupings is not the ultimate step in a long unbroken historical lineage, as the use of a simple genealogical approach might seem to suggest. In fact, it is not my intention here to discover the true historical roots of the neighbourhood system in Java; nor am I interested in making an argument about pan-Asian neighbourliness. Instead, the conclusion drawn here is that these local forms of governance are the product of the social, economic and political needs of various eras, emerging as a long arch of social patterns of behaviour that are visibly and emotionally important to the citizens of the Republic of Indonesia. Rather than genealogical metaphors, a geological metaphor is more apt: community is a precipitate of social, economic and political forms in solution. The long arch is a built one stone at a time, quarried from the needs of a colonial government, for example, to extract labour, or the needs of a local neighbourhood to keep its poorest members afloat. ${ }^{7}$ It is less the historical truth of its origins than its historical character, that is, it is the air of historicity and true origins that clothes the RT/RW system that makes it effective. What makes it locally significant is not only how it is understood to be evidence of the historical continuity of Javanese social organization by kampung neighbours but also how the community form is used as a practical, local ideology of mutual exchange in working class kampung.

This particular idea of community has been enshrined in classic ethnographic descriptions of Java and reiterated in administrations spanning Japanese wartime occupation, Independence-era social reform, New Order government rhetoric and practice, and even now in community activism in the newly democratic post-Reformasi. Yet despite their common constitution as part of state administration, it is not only shared position, but also a felt tradition of mutual support and cooperative endeavour that continues this sense of community. It is no exaggeration to suggest that Clifford Geetz's (1963) notion of shared poverty, whatever its limitations as a description of actual social relations in rural villages,${ }^{8}$ is an apt description of how kampung dwellers describe life in these urban neighbourhoods. That is, masses of lower class and poor people share minimal resources while placing

7 The long arch reference comes from Raymond Williams (1961) and Corrigan and Sayers (1985).

${ }^{8}$ See Alexander and Alexander (1982), Collier (1981), Hart (1986), Hardjono (1987), Husken and White (1989), Kano (1995), Stoler (1977) and White (1989). 
value on common social position and neighbourly exchange. Such descriptions of community harken back to old anthropological debates about the closed corporate peasant community (Wolf 1957, 1986), and indeed, many of the characteristics of this community form are evident in the kampung, despite disagreements about their source. That is, kampung members participate in a suite of activities that define insiders versus outsiders, that signal the importance of shared economic position, that preserve some forms of common property, and that rotate leadership among households in the community. Not only that, as in Geertz's description of the infinitely absorptive character of wet-rice agriculture that accompanies the ideology of shared poverty, kampung neighbourhoods appear to serve as an infinitely absorptive reserve army of labour, much as Geertz's thesis of agricultural involution implies (again, despite the many critiques of its limitations as a description of rural social relations under Dutch colonialism).

This idea of sharing burdens and cooperating in the management of local problems was a powerful ethic in the kampung where I lived and worked, whatever its genesis. Indeed, the idea of cooperation and sharing within the community was such a powerful sentiment that it was used to evaluate neighbours and how well they fit in the kampung. It was a powerful local critique to suggest that someone did not act "kampung" (a critique susceptible to reversal by elites who use it to denigrate the lower class). Despite rising incomes witnessed across more than a decade of fieldwork, kampung neighbours still discuss the benefits of kampung life vis-a-vis life in other sections of the city, perhaps particularly in the new "suburban" developments (perrumahan) that have appeared. My former neighbours made continual reference to the life of friendly cooperation and support to be found in the kampung, and it was not uncommon to hear people discuss not only the merits of kampung life, but also the lack involved in living in some other setting. Here are the words of Bu Soetomo, a local PKK official, comparing her life in the kampung with that in other areas of the city.

In Kota Baru it's yet again different. There if a neighbour dies, the Pak RT sends out announcements. "Oh, Ibu So-and-So has died, later women will be needed [to help]". There is only silence. And they are given announcements [literally invitations]. But here, not so. "Oh, there is someone over there who died". Everyone comes, you know? We help. Its good to live in the kampung. City people ... are more intimate, are nicer than rich people who live in 
complexes. Right? Because there it's not necessary to help. Right? Here we still help one another. ${ }^{9}$

Raymond William's (1985) "structure of feeling" is useful here for several reasons. In many ways, kampung community can be understood as "the distilled residue of the organization of the lived experience of a community over and above the institutional and ideological organization of society." That is, life in the kampung implies, for its residents, more than the organization of neighbourhoods for governance and social welfare supports, and more than the spatial definition given by accepted boundaries of main streets, and more than the classed position of the majority of its inhabitants. Kampung also imply and trigger a range of emotional responses and exchange patterns that are felt to be both important and authentically Javanese. The slametan ritual meal of commensality is just one example of the patterns of exchange and support that connect houses and households in these kampung neighbourhoods. These connections are woven of exchange between women and between families, following the channels of kinship as well as habitual social relationships.

\section{The Slametan}

Kampung life pulses around life cycle events such as births, circumcisions, weddings, and deaths. Central to all life rites is the slametan. Clifford Geertz (1960) most famously described this furtive little ritual of commensality, and despite many political and social upheavals, for the Javanese it seems, the slametan remains a fundamental ritual way that community is recognized and reproduced on a daily basis. In its barest outlines, the slametan includes an invitation to neighbours and close kin. Invitations are made through young people who in the past may have delivered a verbal message from the host family but more frequently now carry a printed and copied invitation. These invitations are often accompanied by a box of food, almost as a kind of pre-exchange of food. In some cases, people

9 "Di Kota Baru sudah jalan lagi. Ada tetangga yang meninggal, Pak RT memberi undangan. 'O, ibu itu meninggal, nanti ibu-ibu perlu [garbled], diam. Kasih undangan. Kalau di sini, ndak. 'O, di sana ada yang meninggal'. Semua datang, ya toh? Kita bantu. Itu enaknya tinggal di kampung. Kota orang [garbled] itu lebih akrab, lebih baik daripada di komplek-komplek orang kaya-kaya itu. Ya? Karena di sana ndak membetulkan bantuan. Ya? di situ kan masih tolong-menolong”. 
are not invited to any meeting or meal but instead informed of an important life event with the printed message and the accompanying food.

In Geertz's classic formulation, the invitations were followed by a common meal hosted by the family in question. The people attending were male heads of households, who only briefly tasted the food in the house of the hosts and then quickly wrapped the remaining food to be taken home and shared with family. The commensality was understated even if central in principle, and the furtiveness was a result of the anxious and awkward matter of eating together, something still not typically done on a daily basis in most Javanese kampung homes.

The Javanese slametan or kenduren has been the subject of much speculation (Hilmy 1999; Beatty 1999; Woodward 1989; Keeler 1987; cf. Bowen 1993). One of the central issues in many of these considerations of the slametan has been its character as an Islamic ritual. The academic disagreement about its origins and meanings is mirrored in popular discussions of the slametan. My neighbours did not always use the word slametan for occasions of community commensal eating but instead the word sembahyangan, or prayer meeting. For example, some argued that the local Catholic prayer meetings were not slametan, because there was nothing being marked such as a birth or death, and no religious official was present. Others argued just as strongly that, of course, these were slametan. The avoidance of the word slametan might be an indication of an avoidance of the Islamic character of that ritual, and yet my experience in the kampung suggests instead that many of the so-called Islamic rituals are understood instead as Javanese rituals, just as the neighbourly sharing and cooperation within the kampung was understood to be Javanese, not just a function of government directives. ${ }^{10}$ The use of the word sembahyangan appears to be less about Islamic sensibilities than it is about the shorthand version of the slametan that is practised at Catholic prayer meetings and at the routine governmentsponsored meetings of PKK and RT/RW officers. What remains in these abbreviated versions are the two aspects of the slametan that have most often gone unremarked in other analyses: its house-based character and the amount of female labour that is required.

${ }^{10}$ See Beatty (1999), Bowen (1993), and Hilmy (1999) for treatments of the slametan as a Islamic ritual. 
The slametan has been described as a ritual focussed on the male head of household as the formal and public representative of a coresident family group. Hosted out of the main front room of the house, the conventional description of the slametan supported a structuralist reading of the house as split into a front, male, public space and a back, female, private space (Rassers 1960; cf. Keeler 1983). By taking the role of the house seriously in the staging of a slametan, we can see this plan of the house is less apt than one that figures its role as conduit to community exchange relationships managed by both males and females.

The typical kampung slametan, in my experience, has both men and women attending. They arrive singly or in same-sex pairs and groups. They politely take off their shoes and enter into the front room whose furniture has been replaced by plastic mats. They politely say "kula nyuwun" (Jv., literally 'I ask' or colloquially 'may I enter') as they duck into the room. People cross the room on their knees or bend low as they quickly find a place next to people of the same sex. This group will wait in a kind of desultory silence, with little chatting, before the tea is handed into the room from the back. Often the back area is concealed with a curtain, so that guests do not see into the interior of the house. Guests hand around the tea in a circle until all have received a glass.

The kampung slametan I participated in illustrate some of the conservative force of this ritual form in the emphasis on Javanese politesse: entry into a house requires formal politeness; heads should be no higher than others; people should wait patiently and quietly; tea must not be drunk until the all have received theirs, a suitable time has passed, and someone has agreed to take the first sip. Although Geertz's adjective of furtive still applies, men and women both attend now and stay longer. In my experience, this has meant that the women sitting together spend a good deal of time arranging their legs, often with a big scarf to cover the knees, getting out hankies and tissues, and applying eucalyptus balm to their arms. The men sit side-by-side, without much talking. They typically smoke, rocking gently in place, often staring up at the ceiling. Fun and festive are not appropriate words for these gatherings, and yet these ritual meals are a commonplace of kampung life.

The food and drink at a slametan are fairly standard. Large quantities of tea are served with a snack of cake or some other sweet along with something fried and salty to be followed ultimately by a slametan meal of varying degrees of luxuriousness. A typical slametan meal in my old neighbourhood was rice with a coconut-based sauce, 
some chicken, hot sauce (sambel), and a shrimp cracker. The food is typically served only after any business, such as praying, is complete, and only then is there much conversation. People may eat their food hurriedly or be more leisurely. The only food wrapped to take home are the lumpia (eggroll) or pieces of cake that precede the meal, and these are typically taken to young children or grandchildren.

The official hosting of a slametan may well be done by a male head of household sitting in the front room, although women can perform this function as well. A focus on the host in the front room can conceal how the slametan produces a common space opening out the front door but also into the interior of the house, both thresholds connecting the house to the greater community through exchange relationships. During the slametan, this room becomes, in essence, a kind of public space. Although within an individual house, the slametan as an event of community feeding is based on the incorporation of people related by proximity and by kinship into a common space. The ritual work of the slametan, then, transforms community members into a common group through the act of commensality within a house (Carsten 1995).

Despite some of the changes out front, in back, the work of preparation and serving remains much the same. Female labour is required to stage a slametan of even the smallest and most minimal kind. The slametan does indeed take place either in front of the house or in its main front room, but this cannot take place without all the backdoor labour of women (Newberry in press 2005). In the day preceding the slametan, the food must be bought and prepared, the dishes and glasses wiped, and the house cleaned. The food itself is often days in the planning, although there are more opportunities for buying the snacks now, taking some of the pressure off the women who are in charge of logistics. For a moderate to large slametan, the women of the house must call upon other women outside the immediate family to help in the preparations. The women who are called upon may be extended kin, near neighbours, and most importantly, women whom they have helped in the past.

The women who come to help stage a slametan, arrive and enter typically through back doors, not front doors. They will often arrive bringing food or snacks for those doing the work, and they will bring their own towel and knife for larger slametan work sessions. The companionship and fun of the slametan is much more pronounced on the backdoor side of the slametan. Women and young people are free to dress and act without the same restraint. Jokes and laughter are frequent as is the rough bossing of kitchen work. For the most 
part, the work is routine, and things flow smoothly. During these backdoor labour sessions there is frequent reckoning of how much food is needed and how many people might come. There is no confirmation of attendance in response to invitations, so it is always a reasoned guess about how many will be there to feed. And it is here that the significance of the backdoor is paramount.

In the event of having too little, there must be a way to escape to run to the neighbours or a local food stall to get what is needed. This escape hatch function of back doors should not be underestimated. During my initial fieldwork, my neighbours often seemed to talk of nothing else than how awful my new house was because it had no back door. This evaluation and critique served as a particularly telling index of the structure of feeling in kampung based on mutual exchange and support. My house was seen as fundamentally flawed because the daily exchanges that take place out of back doors were impossible. In fact, the slametan I attempted to hold were hosted out of my next-door neighbour's house instead, and the food was carried from her back door to my front door to be served. This rather amazing approach to holding a slametan was based entirely on the desire to have a back door that would allow for management of the meal through the labour of women mobilized out of the back section of the house.

When seen from the back door, the slametan is less about the formality of male heads of households than it is the network of services and goods that flow out of and through back doors, as well as front doors. Nancy Sullivan $(1983,1994)$ has described these as rewang networks for a downtown kampung in Yogyakarta. Ngrewang (Jv., to help) is used to refer to the pattern of reciprocal labour exchange between women that makes slametan possible. In a slametan hosted at my house during my early fieldwork, I was shown very clearly how these patterns worked. After the meal was over and the guests had left, there was food to be distributed. I had thought that this food would be shared with those who were less well-off in the neighbourhood. In fact, many of the poorest in the kampung did not attend slametan with any regularity, and as I came to see, this was because they could not enter into the mutuality of exchange that is expected. The fact that the food was distributed along established channels defined by female labour became clear as I suggested that food be sent to various poor neighbours only to have them rejected for what seemed to me silly reasons.

What emerged from the patterns of those who were given food was that families in established exchange relationships were sent food, 
and these were typically the houses of women who had helped earlier in the day. The only really needy families to receive were kin, who were categorically in exchange relationships. Otherwise, food followed paths of women's labour out of the back door of houses. A focus on the front door and the people fed during the slametan is only a partial picture; it is the flow of women, resources, services, and food through the back door-before, during, and after-that makes the slametan possible. And this reciprocal, mutually reinforcing flow of resources and aid defines houses less as discrete structures than as nodes and conduits in a network of neighbourly exchange and connection. These networks of exchange and support are not without real benefits for kampung residents whose economic fortunes are often quite variable. Indeed, the use of community forms to recognize these patterns of exchange and support suggests their crucial importance to social reproduction in these working class enclaves.

These paths defined by women were, of course, invisible from the front door of the house. What might seem to others a ritual of commensality focussed on the formal exchange of food between male heads of households was in fact a community event that requires kin-connected households and those connected through female relationships (see Cartsen 1995 for a similar argument about feeding and community for Malaysia). This reading of the house is no different than other treatments of the invisible houses of women (Jean Comaroff 1985; Wolf 1972) that were often overlooked in early structuralist analyses. Yet, this important insight needs to be kept in mind when we turn to understanding how the state has used these sites of social reproduction in its organization of communities and in its governance practises.

Whatever else it may be, the slametan is clearly a community ritual. Those in attendance for these small and regular events were typically neighbours and close-by kin. In my experience, while the more wellto-do are involved in slametan patterns that may incorporate people and family from outside the immediate vicinity, in this working class neighbourhood, the slametan is still a local, neighbourhood ritual staged in a house. Thus, patterns of invitation and labour exchange were longstanding and tended to reproduce sets of relationships that endured for some time. The structure of feeling that is the kampung, above and beyond its organizational outlines, was lived and given flesh in these neighbourhood slametan.

Perhaps it is not surprising that this community shares much with that enshrined in ethnographic description of Java, in Independence 
era social movements, in government rhetoric, and even now in newly democratic post-Reformasi era non-governmental rhetoric. Even so, the ideology of a mutually supportive community of people who help one another in times of need is a powerful daily practise in kampung life, one realized quite clearly in the slametan but also in countless acts of neighbourliness and exchange. The community reiterated in slametan is one defined by mutual support and exchange and the cooperative work of women in the feeding of others. Consequently, these rituals highlight the networks of labour and exchange that women monitor and maintain within the community. ${ }^{11}$ The same patterns of labour exchange and mutual support that make slametan possible are the basis for women's general kampung social work as well as the support for the broader informal economy of the kampung. These networks are realized with each successive slametan. Even more, these networks channel the social welfare work assigned to women through government programs such as PKK.

\section{PKK and Rituals of Domestic Community}

The prevalence of PKK in Java is plain to any who care to see. Boards with the ten important programs of PKK appear at the entrance of kampung neighbourhoods and local meeting halls. These ten principal programs range from learning the state ideology to support for housing and home economics cooperatives, to health planning. ${ }^{12}$ The message of PKK also appears on large city billboards and in other print media. In practice, PKK serves as the state mobilization of female labour

${ }^{11}$ Carsten (1995) and Brenner (1998) both deal with the role of women in mediating the relationship between family and community. Brenner analysis of women's roles in "domesticating" money for the consumption of the family is particularly useful here.

12 The ten programs are

1) comprehension and practical application of Pancasila;

2) mutual self help;

3) food;

4) clothing;

5) housing and home economics;

6) education and craft skills;

7) health;

8) development of cooperatives;

9) protection and conservation of the environment;

10) health planning (read as family planning). 
to provide no-cost and low-cost social welfare to local communities. The women of PKK conduct the monthly baby weighings, work to spread information about health practices, collect and distribute small amounts of money to the neighbourhood sick and poor, participate in training and credit programs, and of course, help in the dissemination of information about KB (Keluarga Berencana, Planned Family), the national birth control program (Marwan 1972; Rudini 1988).

PKK is central to state-sanctioned projects directed at the management of the "biosociality of communities" (Rabinow 1999). The activities of PKK are targeted at the bodies of women as the sites for control through the birth control program, but also as agents and managers of local communities for the government goals of development. In a kind of double positioning, women are situated as both the primary recipients of government directives about health and social welfare as well as the primary voices for such "state"-ments to the rest of the community. The state-sponsorship of housewives as local community welfare workers has the great advantages of extremely low-cost and increased efficacy insofar as women are influenced more directly by their close neighbours than by other government "officials."

Still, PKK occupies a vexed position in the lives of local women, providing both access to health and education resources but also the entry of state-level surveillance into their lives. The "biosociality" of this part of community governance and social management is quite clear in its involvement in the extension of birth control devices and education through the work of PKK women. Perhaps the quintessential act of governance as social management effected through PKK is the arrival of PKK kader (cadre) at the door of her neighbour, first to record the method of birth control used, and second, to offer other contraception if needed.

One other aspect of PKK that has received international attention and that suggests the matrix of social belief and action that support slametan as well is the monthly weighing of babies under five years of age. Once a month, each RW section organizes, in conjunction with the local health officer and clinic, an afternoon devoted to checking the weight and developmental progress of babies. Typically, women from a single RT will take charge on a rotating basis. They will set up the place, if not at a house then at the local meeting hall or sometimes a school. They will also cook and serve the food that is provided to each child who is weighed. In this instance, the role of women in mobilizing social labour for community support and feeding is once again clear. The skills for managing the slametan are similar and are made use 
of in this government-sponsored ritual of management based on and extending notions of maternal care (Fox Genovese 1991; hooks 1990).

The structure of the PKK hierarchy matches that of the RT/RW system and the general administrative hierarchy that extends above it; therefore, the leader of PKK at its most local levels is the Ibu RT, or Mother RT, and on up through the Ibu RW to the ranks of the civil service. Both organizational structures are composite, that is, both are understood to be arms of the government and yet both are "staffed" by unpaid, local people who are expected to volunteer to participate. Although not all men will serve as the local Pak RT or Pak RW, all women by virtue of being married, are expected to participate in PKK. The structure of feeling that is the kampung serves to underwrite this participation. That is, despite the fact that many women have a lively disdain for PKK, longstanding patterns of mutual exchange support the posting of women as local social service workers.

PKK's hybrid historicity, like that of the community idea itself, is evident in the many manifestations of community-level organizations run by and through women. In my work with neighbourhood women on the role of PKK in their domestic lives, I found many women looking back nostalgically to WK (Wanita Katolik, Catholic Women), an organization much beloved by the older women in this surprisingly Catholic kampung. In fact, so strongly did some of these older women feel about this organization, they still met on a semi-regular basis to have tea and chat. Other women fondly remembered the RK (Rukun Kampung, or Harmonious Kampung), a unit that preceded the RW system and that covered a much larger area of the kampung. My nearest neighbour said she missed getting to meet with the larger group and see people from other parts of the kampung. She resisted, as did many of my neighbours, the newer, smaller Dasa Wisma (or 10 houses) that was being instituted at the time of my original fieldwork (1992-3).

My neighbours often made fun of PKK and the administrative work of the RT/RW, and yet these small units were used over and over again and were called upon to settle local disputes, provide aid, and manage common problems (water, sanitation, roads). Other community groups would crop up as well, like the men's arisan that had appeared in by 1997. The arisan, or rotating credit lottery, like the slametan, is a kampung fixture. Many women reported that they attended local meetings just to participate in the arisan and take home, in turn, the collected money at the monthly meeting. The arisan and the slametan both index the economic position of 
kampung residents and the use of local community practises as part of bureaucratic routine.

PKK is not as well liked as other more warmly remembered organizational structures such as those mentioned earlier. Nonetheless, as my research shows, the strength of PKK, like the ideal village community, lies not with its origins, which are in any case subject to dispute, but instead in its practice in everyday life. The activities of PKK may be resented by women who work outside the home, but they still use its structure to accomplish the very kind of needful community that PKK itself perpetuates. In my experience, kampung women derided the program (using the abbreviation to make the pun, Perempuan Kurang Kerja or Women Without Enough Work to Do) even as they make use of it in their daily lives (cf. Tsing 1993). For example, working women use the activities of PKK and the RT/RW to discharge their duty to the community in an organized and efficient manner rather than individually which would take too much time. Returning to the opening example, the women of my RT chose to use the structure of PKK to discharge the duty of asking forgiveness of their neighbours as a group rather than as individual women and families (see N. Sullivan 1983 for a similar example). Beyond the irony of a housewives organization providing support for working women, it is the redirection of its structure for uses other than government directives that is of interest here. In a sense, rule is redistributed through these local practises. Was this yearly ritual of apology part of the government's program for community development? Clearly not. And yet, when the instruments of governance are used to deal with exigencies of daily life in a densely lived, socially intimate neighbourhood space, the question of intention becomes less significant than what is accomplished: both the reinforcement of community ties, but also the subtle shading-yet again —of community mutuality by the shadow of state rule.

The functions of PKK resonate with Garon's careful historical account of women's associations in Japan (1993, 1997). These associations emerged, at times at odds with a nascent feminist movement and at times in step with its leaders, much as they did in Indonesia. ${ }^{13}$ As Garon suggests, "we cannot hope to comprehend

13 The beginnings of what would become the national housewives association can be traced to the same period of awakening and independence in the early 1900 as other nationalist organizing (see Locher-Scholten and Neihof 1987; Suryakusuma 1991, 1996; Surychondro 1984; Vreede-de-Steurs 1960; Wieringa 1988, 1993). During this 
relations between the Japanese state and civil society without examining the roles of women, sexuality, and other aspects of gender" (1993: 6; see also 1997). I cannot explore fully here the relationship between the Indonesian state's relationship to early nationalist women's associations and the subsequent shift to a government-sponsored suite of programs, but only note that this shift from autonomous political interest groups to state-sponsored mass organizations is the same as described for community organization. In this instance, the establishment and support of PKK reflects an extension of the domestic sphere to social management of communities more generally, and especially to the configuration of local community as an extended household subject to local women's management. ${ }^{14}$ As Garon documents for Japan, this extension of domestic duties into a public sphere was the only public manifestation of women's politics allowable under some regimes and in some periods. This extension of the domestic questions the suitability of the concept of civil society to capture the space for challenge to the reach of the state and the interplay of local interest and state-level governance (Erikson 2001).

As in Japan, the Indonesian government used-indeed, continues to use-the offices of PKK and its members as part of a campaign of moral suasion (Garon 1993; 1997) to inculcate and convince the populace of a particular set of moral values. In the case of Indonesia under Suharto, these values followed upon the wholesale adoption of modernization theory and the logic of development. Yet, these moral values are not laid, layer-cake fashion, over existing values; rather, they are interpolated with other moral registers. The Indonesian government's use of moral suasion does not contradict so much as amplify and extend local values of community and women's roles in it.

early nationalist period, women's groups were also advocating on behalf of poor women through health and education initiatives. Wieringa (1988) provides a telling history of the vigorous and autonomous, Independence era women's organization GERWANI (from Women's Movement). The leaders of GERWANI promoted kindergartens, credit cooperatives, literacy courses, assistance to women, and attention to housewives. Although this independent organization was banned following the alleged coup that gave power to Suharto, it was replaced structurally by the government-sponsored housewives program, PKK.

${ }^{14}$ Fox-Genovese (1991) describes the social housekeeping of women as one of the legitimate ways that women can appear in the public realm. Also see Cott (1977), de Grazia (1992), Kerber (1980), Koonz (1987), and Matthews (1987) on the extension of women's domestic roles in revolutionary movements. 
For Indonesia, as for Japan (Garon 1993, 1997), this is less a story about government domination and collaboration than it is an example of how organizations sponsored by the national government and aimed at the social management of "civil society" are not the end of the story but the beginning. The staging of neighbourhood rituals in the guise of government meetings or staging government meetings in the guise of neighbourhood rituals illustrate how women's roles in kampung communities work in and around such organizations. The reach of the official governance is incomplete, and the popular, positive practice of neighbourly exchange is in conversation with government-provided ideologies of community organization.

So what, then, do furtive little rituals of commensality and community apologies in working class neighbourhoods in Java have to do with the state? What is the significance of using local PKK meetings to meet other community obligations or vice versa? If the state is the very organ of moral thought as Durkheim would have it (Corrigan and Sayer 1985), so is the community form in Indonesia and Java. The community represents a particular moral form that is both given by the administrative organization of various state regimes but is also informed by local understandings of what appropriate community is made of and through. That is, the social relations of community are made and re-made by neighbours involved in dense networks of exchange that are made meaningful not only because they are given by the government but because they mean something in local terms as well. Whatever its elaborations or elisions, the shell of the slametan is a powerful symbol of commensality and the transubstantiation of people living nearby into a community (cf. Carsten 1995).

Interestingly enough, the community in Indonesia may be seen as having the same characteristics imputed to the state; that is, as a routine and ritual of rule, as a moral economy, as the very organ of moral thought, as a site of contestation and difference, as a kind of public, and as historical as well as historically charged. Kampung residents who belittle the activities of PKK and the RT/RW but use them both to maintain social relations of community and accommodate the exigencies of marginal economic positions do not think of the community form as given from the government. Kampung community is understood to be a traditional Javanese cultural form even as it is used as a measure for neighbour's behaviour, as an active ideology about class position and appropriate neighbourly conduct. Here state-driven ideology becomes entwined with the positive cultural making of kampung neighbourhoods as particular 
kinds of places, places that are realized simultaneously as social formations and political instrumentalities: structures of governance and structures of feeling.

\section{The Culture of Administration}

At what point may we legitimately separate state instrumentalities such as the RT/RW system and PKK from networks of local hierarchy and exchange practised in and through it? One way to understand the national housewives organization and the neighbourhood section system is as forms of administered mass organizations, following Kasza (1995). In Kasza's analysis of conscription society, administered mass organizations represent the relatively recent power of states to mobilize large numbers of people. This ability to do mass organizing produced interest groups and political parties in some countries, but in highly "mobilizational" single-party or military-bureaucratic regimes, it produced the administered mass organization (hereafter AMO; 1995:1). For Kasza, the difference between an AMO and an interest group is basic: "the AMO is created not to serve an interest defined within the organization but to further interests specified by external regime agencies" (Kasza 1995:9); in fact, the AMO is an "anti-interest" group. As Kasza describes them, there is a difference between a "regime's ruling institutions" and its AMOs, which are not allowed to participate in policymaking or the direct recruitment of state leaders. And AMOs are not to be confused with nongovernmental organizations (NGOs), because the AMO is understood to be reflexive of state or regime interests. Rather, the fixing of AMO goals and operating procedures is done by regime officials. Its structure is symmetrical with the regime's ruling institutions as well as its vertical articulation. Its membership is inclusive, based on whole categories of people, by age, gender, workplace or residence. Coercion occurs in enrollment, and alternative organizations are prohibited. Local officers are elected or appointed from the mass membership, and concomitantly, provincial and national leadership selected from the ranks of the regime's governing institutions. Finally, finances are controlled by the regime $(1995: 27) .{ }^{15}$ The fit of this description for the RT/RW section system and for PKK is striking.

15 The model and progenitor for the AMO was the mobilization of large segments of the population to win wars. World War I was the cause of the emergence of the AMO in Japan, Italy and the Soviet Union, according to Kasza (1995), and a key part of his analysis is that all other manifestations of this form of mass organization 
Moreover, in the case of the national housewives association, the Indonesian state's reach to use the elements of popular social movements is clear, and despite challenges to the primordial peasant village, the LKMD certainly was used to capture a non-governmental program to help organize rural areas. In this we see as well the "statization" of popular movements described by Mamdani (1996). In Kasza's analysis, we are left with the conscription society; in Mamdani's, decentralized despotism and the bifurcated state. What then the possibility for autonomy or social change?

In Kasza's portrait of the AMO, its structure and its relationship to the ruling regime appears, in more than one way, fixed. Although admitting there is some flexibility in how it is used, Kasza suggests that only rarely have AMOs been used as a channel for autonomous social change. The picture is one of form and function as static and fundamentally authoritarian. In fact the most important principle of the AMO may be that it is often used as an obstacle to true political participation. This conclusion is commensurate with Mamdani's notion that universal civil rights are deferred under a form of indirect rule that makes recourse to tradition and customary practise as a form of administration.

Clearly, kampung women have been posted as state-sponsored social welfare workers and the neighbourhood section system has been used to administer local communities. Does the use of the slametan in local meetings then represent the complete enclosure of the community form and women's work within it as reflexive of regime interests, or does it suggest a gap in the reach of state power? To understand both the interpolation of women as subjects of government policy and also as the lynchpins in the structure of feeling that is the kampung, their roles as managers of social labour for the state but also for their communities must be considered. In fact, it was clear that my kampung neighbours were involved in a pervasive set of communal practices that often took shape through administrative units that were community based. And often, they described their use of these practices as being authentically Javanese and part of a long-standing heritage of mutual aid and support. In my own fieldwork, I found that dense networks of kin and neighbours were used for mutual support among the poorer

were influenced by these cases. For Indonesia, the Japanese AMO was the prototype, introduced during WWII to Java and then subsequently used by newly independent Indonesia. 
and working class to stay afloat, and their cooperation was often organized through a frame of community support.

This art of social management is strongly reminiscent of Foucault's governmentality which can refer to the "art of managing the economy and the population for the common welfare of all" (Gupta 1995), but the focus on management and governmentality alone seems insufficient. We may emphasize the mentalité implied in governmentality as implying habits of the mind that are emergent across the historical trajectory of a social formation, in the fullness of time. Yet, my reference to Williams's structure of feeling suggests a slightly different emphasis. That is, the emphasis is "not a shared ideology but a common material and meaningful framework for living through, talking about, and acting upon social orders characterized by domination" (Roseberry 1994:361). Or as Alonso describes Corrigan and Sayer's work on English state formation:

state formation is cultural revolution ... in which everyday state routines, rituals, activities, and policies, which are themselves material cultural forms, constitute and regulate the social making of meaning and of subjects (1994:380).

"Anchored in relations of inequality" (Alonso 194:380), a structure of feeling implies both the pervasiveness of state-given routines, rituals, and rules, as one might expect from a governmentality approach, but it also directs attention to social relations in solution, that is, to the emergent character of this cultural process. And this accords well with the conception of kampung class offered here; that is, it is the relation of kampung as opposed to both rural peasantry and urban elites that contributes to its constitution as a structure of feeling. The dynamism of this relation is evident as well in local ideas about community and women's roles in community along with the gender ideologies implied in PKK, which cannot be reduced to fixed forms. Such forms "become social consciousness only when they are lived, actively, in real relationships, and moreover in relationships which are more than systematic exchanges between fixed units" (Williams 1977:130). As Williams notes, there is always a fundamental tension between "received interpretation" and "practical experience". These forms do not require definition, classification, or rationalization to "exert palpable pressures" and set limits on experience and action.

Pemberton (1994) has argued that state-administered culture in New Order Indonesia $\left(1945^{-1997)}\right.$ was a series of historical 
displacements that robbed ritual and cultural forms of their effective power. As he says of state-sponsored ritual events:

Such explicitly cultural New Order gesturing confounds common anthropological assumptions of an underlying cultural order.... The power of an indigenous discourse so self-consciously concerned with what constitutes "authentic" (asli) Javanese culture, with a "tradition" (tradisi) that must be preserved at all costs, operates to recuperate the past within a framework of recovered origins that would efface, for the sake of cultural continuity, a history of social activism from the late 1940s to the mid-196os (Pemberton 1994:9).

Here we see administration understood as a threat to the vitality of culture (cf. Adorno 1990). Yet, the inevitable reach of administration to take over the culture does not mean the end of culture; there remains room for the active play of culture in and through administration. For Pemberton, New Order state ritual was the burial shroud of Javanese culture, bearing the imprints of a once living thing but in itself a shadowy representation worshiped by those who are in effect mourners and not folks who are living and changing Javanese culture everyday (see for example his reference to doing "salvage ethnography," 1994:223). Reports of the death of Javanese culture, however, are premature.

In my most recent trip to Java, I worked with a local NGO, USCSatunama, whose work includes democratization, a goal of many grassroots organizations in the post-Reformasi era that has seen the end of Suharto's longstanding regime and the beginning of the first democratically elected legislature and president. I was able to attend several meetings of small women's groups devoted to building social and economic capital among the poor by encouraging their kerajinan kecil (small industries). These predominantly home-based enterprises ran the gamut from food seller to laundress to beauty salon operator. At my first meeting, I stepped off the motorcycle of one of my Javanese colleagues and stepped over a threshold to be greeted by yet another neighbourhood meeting held in the house of one of its members. Women seated around the perimeter of the room welcomed us to what was, in essence, another abbreviated slametan-style meeting, this time held to support the nongovernmental organization of poor women. And so once again, the work of women in houses within communities is the basis for administration.

Active consent to be ruled is less a daily accomplishment than a daily question. The use of slametan as rituals of rule in working class, urban kampung suggests that the Indonesian state is remade, from 
the ground up, at the most intimate levels of life but in constant tension with local, moral terrain that defines both the possibilities but also the impossibilities of its completeness. Structures of feelings as social experiences in solution do not deny the real, concrete exercise of power in Indonesia, but point towards the moment when local cultural forms expert palpable influence on what the precipitate is.

The perspective on the state here is resolutely low, and it is meant to privilege neither the institutional structure of any state nor to resort to locating rule only in the repertoires and routines of performance and discourse alone. It is the active accomplishment of rule in the houses of neighbours who see themselves as bound by a common ethos of shared exchange that should remind us of the culture involved in administration. ${ }^{16}$

\section{References}

Abrams, Philip. 1988[1977]. Notes on the Difficulty of Studying the State.Journal of Historical Sociology 1 (1):58-88.

Adorno, Theodor. 1990. Culture and Administration. In Philosophical Streets: New Approaches to Urbanism. Dennis Crow, ed. Pp. 27-51. Washington, DC: Maisonneuve Press.

Alexander, J. and P. Alexander. 1982. Shared Poverty as Ideology: Agrarian Relationships in Colonial Java. Man 1:597-619.

Alonso, Ana. 1994. The Politics of Space, Time and Substance: State Formation, Nationalism and Ethnicity. Annual Review of Anthropology 23:379-405.

Antlov, Hans. 1995. Exemplary Centre, Administrative Periphery: Rural Leadership and the New Order in Java. Dordrecht: Curzon Press.

2003. Not Enough Politics! Power, Participation and the New Democratic Polity in Indonesia. In Local Power and Politics in Indonesia. Edward Aspinall and Greg Fealy, eds. Pp. 72-86. Singapore: Institute of Southeast Asian Studies.

Beatty, Andrew. 1999. Varieties of Javanese Religion: An Anthropological Account. Cambridge: Cambridge University Press.

Benda, Henry, James Irikura and Koichi Kishi. 1965. Japanese Military Administration in Indonesia: Selected Documents. Southeast Asia Studies, Translations Series no. 6, Yale University.

Bestor, Theodore. 1989. Neighborhood Tokyo. Stanford: Stanford University Press.

${ }^{16}$ In a similar argument, Day (2002) advocates consideration of the role of culture for understanding state formation in Indonesia. Although not entirely in agreement with Midgal (2001), both Day and Migdal signal a move toward emphasizing a "statein-society" approach to the analysis of rule. Day's use of social field is commensurate with the work described here, especially in its emphasis on whole ways of life, following Williams (1977). Despite these shifts in approaches to the study of the state, a recent compilation of scholarship on the effects of decentralisation in Indonesia (Aspinall and Fealy 2002) still fails to take seriously the role of these small local groups in urban Indonesia and the centrality of women's roles and the domestic within communities of administration. 
Boris, Eileen and Peter Bardaglio. 1983. The Transformation of Patriarchy: The Historic Role of the State: In Families, Politics, and Public Policy. Irene Diamond, ed. New York: Longman.

Bowen, John. 1986. On the Political Construction of Tradition: Gotong Royong in Indonesia. Journal of Asian Studies 45(3):545-561.

- 1993. Muslims through Discourse: Religion and Ritual in Gayo Society. Princeton: Princeton University Press.

Breman, Jan. 1980. The Village on Java and the Early Colonial State. Rotterdam: CASP, Erasmus University.

1988. The Shattered Image: Construction and Deconstruction of the Village in Colonial Asia. Dordrect: Foris Publications.

Brenner, Suzanne. 1998. The Domestication of Desire: Women, Wealth and Modernity in Java . Princeton: Princeton University Press.

Burchell, Graham, Colin Gordon, and Peter Miller, eds. 1991. The Foucault effect: Studies in Governmentality. Chicago: University of Chicago Press.

Carsten, Janet. 1995. The Substance of Kinship and the Heat of the Hearth: Feeding, Personhood, and Relatedness among Malayans in Pulau Langkawi. American Ethnologist 22(2):223-242.

Chatterjee, Partha. 1989. Colonialism, Nationalism, and Colonised Women: The Context in India. American Ethnologist 16(4):622-633.

Collier, W. 1981. Agricultural Involution in Java. In Agricultural and Rural Development in Indonesia. G. Hansen, ed. Boulder, Colorado: Westview.

Comaroff, Jean. 1985. Body of Power, Spirit of Resistance: The Culture and History of a South African People. Chicago: University of Chicago Press.

Comaroff, Jean and John Comaroff. 1999. Introduction. In Civil Society and the Political Imagination in Africa: Critical Perspectives. John and Jean Comaroff, eds. Pp. 1-43. Chicago: University of Chicago Press.

Corrigan, Philip and Derek Sayer. 1985. The Great Arch: English State Formation as Cultural Revolution. Oxford: Basil Blackwell.

Cott, Nancy. 1977. The Bonds of Womanhood: "Woman's Sphere" in New England, I 8ooI 835. New Haven: Yale University Press.

Curtis, Bruce. 1995. Taking the State Back Out: Rose and Miller on Political Power. The British Journal of Sociology $46(4): 575^{-589}$.

Davidoff, Leonore and Catherine Hall. 1987. Family Fortunes: Men and Women of the English Middle Class. Chicago: University of Chicago Press.

Day, Anthony. 2002. Fluid Iron: State Formation in Southeast Asia. Honolulu: University of Hawai'i Press.

Dean, Mitchell. 1999. Governmentality: Power and Rule in Modern Society. London: Sage.

de Grazia, Victoria. 1992. How Fascism Ruled Women, Italy, I92 2-1945. Berkeley: University of California Press.

Djdjadningrat-Niewenhuis, Madelon. 1987. Ibuism and Priyayization: Path to Power? In Indonesian Women in Focus: Past and Present Notions., E. Locher-Scholten and Anke Neihof, eds. Pp. $43^{-} 5^{1}$. Dordrect: Foris Publications.

Donzelot, Jacques. 1979. The Policing of Families. New York: Pantheon.

Dumont, Louis. 1966. The 'Village Community' from Munro to Main. Contributions to Indian Sociology 9:67-89.

Engels, Fredrich. 1942[1902]. The Origin of the Family, Private Property and the State, in the Light of Researches of Lewis H. Morgan. New York: International Publishers.

Eriksen, Stein Sundstøl. 2001. The State We're In: Recent Contributions to the Debate on State-Society Relations in Africa. Forum for Development Studies 2:289307 .

Evans, Peter, Dietrich Rueschemeyer, and Theda Skocpol, eds. 1985. Bringing the State Back In. Cambridge: Cambridge University Press. 
Ferguson, James and Akhil Gupta. 2002. Spatializing States: Toward and Ethnography of Neoliberal Governmentality. American Ethnologist 29(4):981-1002.

Foucault, Miche. 1979. Governmentality. Ideology and Consciousness? In The Foucault Effect: Studies of Governmentality. G. Burchell, C. Gordon, and P. Miller, eds. Pp. 87104. Reprint. Chicago: University of Chicago Press.

Fox-Genovese, Elizabeth. 1991. Feminism Without Illusion: A Critique of Individualism. Chapel Hill: University of North Carolina Press.

Garon, Sheldon. 1993. Women's Groups and the Japanese State: Contending Approaches to Political Integration, 1890-1945. Journal of Japanese Studies 19(1):5-41. 1997. Molding Japanese Minds: The State in Everyday Life. Princeton: Princeton University Press.

Geertz, Clifford. 1960. The Religion of Java. Chicago: University of Chicago Press.

1963. Agricultural Involution: The Process of Ecological Change in Indonesia. Berkeley: University of California Press.

1980. Negara: The Theatre State in Nineteenth-century Bali. Princeton: Princeton University Press.

Goh, Taro. 1998. Communal Land Tenure in Nineteenth-century Java: The Formation of Western Images of the Eastern Village Community. Canberra: Department of Anthropology, Research School of Pacific and Asian Studies, the Australian National University.

Goldstein, Daniel. 2004. The Spectacular City: Violence and Performance in Urban Bolivia. Durham: Duke University Press.

Guinness, Patrick. 1986. Harmony and Hierarchy in a Javanese Kampung. Singapore: Oxford University Press.

1991. Kampung and the Streetside: Yogyakarta under the New Order. Prima $5^{1: 86-98 .}$

Gupta, Akhil. 1995. Blurred Boundaries: The Discourse of Corruption, the Culture of Politics, and the Imagined State. American Ethnologist 22(2):375-402.

Habermas, Jurgen. [1962] 1989. The Structural Transformation of the Public Sphere: An Inquiry into a Category of Bourgeois Society. Thomas Burger with Frederick Lawrence, trans. Reprint. Cambridge: MIT Press.

Hadiz, Vedi. R. 1997. Workers and State in New Order Indonesia. Routledge Studies in the Growth Economies of Asia. London: Routledge.

Hansen, Thomas Blom and Finn Stepputat. 2001. States of Imagination: Ethnographic Explorations of the Postcolonial State. Durham: Duke University Press.

Hardjono, Joan. 1987. Land, Labour and Livelihood in a West Java Village. Yogyakarta: Gadjah Mada University Press.

Harrison, Rachel and Frank Mort. 1980. Patriarchal Aspects of Nineteenth-Century State Formation: Property Relations, Marriage and Divorce, and Sexuality. In Capitalism, State Formation and Marxist Theory, edited by Philip Corrigan. London: Quartet Books.

Hart, Gillian. 1986. Power, Labor, and Livelihood: Processes of Change in Rural Java. Berkeley: University of California Press.

Harvey, David. 1990. The Condition of Postmodernity. Cambridge: Blackwell.

Herzfeld, Michael. 1992. The Social Production of Indifference: Exploring the Symbolic Roots of Western Bureaucracy. Chicago: University of Chicago Press.

Hilmy, Masdar. 1999. Islam and Javanese Acculturation: Textual and Contextual Analysis of the Slametan Ritual. Thesis written in partial fulfillment of the requirements of the degree of Master of Arts, McGill Univeristy.

Hooks, Bell. 1990. Yearning: Race, Gender, and Cultural Politics. Boston: South End Press.

Husken, Frans and Benjamin White. 1989. Java: Social Differentiation, Food Production, and Agrarian Control. In Agrarian Transformations: Local Processes and the State in Southeast Asia. Gillian Hat, Andrew Turton, and Benjamin White, eds. Pp. $235^{-26}$. Berkeley: University of California Press. 
Jessop, Bob. 2001. Bringing the State Back In (Yet Again): Reviews, Revisions, Rejections, and Redirections. Electronic document, http://www.comp.lancs.ac.uk/ sociology/soco7orj.html., accessed June 2002.

Joseph, Gilbert and Daniel Nugent. 1994. Everyday Forms of State Formation. Berkeley: University of California Press.

Kano, Hiroyoshi. 1979. The Economic History of Javanese Rural Society: A Reinterpretation. The Developing Societies 17(4): 3-22.

Kasza, Gregory. 1995. The Conscription Society: Administered Mass Organizations. New Haven: Yale University Press.

Keeler, Ward. 1983. Symbolic Dimensions of the Javanese House. Working Paper No. 29, Monash University. Melbourne: Australia. Press.

Kemp, Jeremy. 1988. Seductive Mirage: The Search for the Village Community in Southeast Asia. Dordrecht: Foris Publications.

Kerber, Linda. 1980. Women of the Republic: Intellect and Ideology in Revolutionary America. Chapel Hill: University of North Carolina Press.

Koonz, Claudia. 1987. Mothers in the Fatherland: Women, the Family and Nazi Politics. New York: St. Martin's.

Lemke, Thomas. 2001. 'The Birth of Bio-Politics': Michel Foucault's Lecture at the College de France on Neo-liberal Governmentality. Economy and Society 30(2):190207.

Mamdani, Mahmood. 1996. Citizen and Subject. Princeton: Princeton University Press.

Marwan, Sihi Saudah. 1972. Pendidikan Kesejahateraan Keluarga (PKK). Suarkarta, Indonesia: C.V. Ramadhani.

Migdal, Joel. 2001. State in Society: Studying How States and Societies Transform and Constitute One Another. Cambridge: Cambridge University Press.

Mitchell, Timothy. 1988. Colonising Egypt. Berkeley: University of California Press.

Pateman, Carole. 1988. The Sexual Contract. Stanford: University of California Press.

Pels, Peter. 1997. The Anthropology of Colonialism: Culture, History, and the Emergence of Western Governmentality. Annual Review of Anthropology 26:163-83.

Pemberton, John. 1994. On the Subject of Java. Ithaca: Cornell University Press.

Putnam, Robert D. 1993. Making Democracy Work: Civic Traditions in Modern Italy. Princeton: Princeton University Press.

Rabinow, Paul. 1999. Artificiality and Enlightenment: From Sociobiology to Biosociality. In Health Studies: A Critical and Cross-Cultural Reader. Colin Samson, ed. Pp. 50-6o. Oxford: Blackwell.

Rassers, W.H. 1960[1925]. Panji, the Culture Hero: A Structural Study of Religion in Java. The Hague: Martinus Nijhoff.

Rigg, Jonathon. 1994. Redefining the Village and Rural Life: Lessons from South East Asia. The Geographical Journal 160(2):123-135.

Robison, Richard. 1986. Indonesia: The Rise of Capital. London: Allen \& Unwin.

1996. The Middle Class and Bourgeoisie in Indonesia. In The New Rich in Asia: Mobile Phones, McDonald's and Middle-Class Revolution, Richard Robison and D. S. G. Goodman, eds. Pp. 77-101. London: Routledge.

Rose, N. and P. Miller. 1992. Political Power Beyond the State: Problematics of Government. The British Journal of Sociology 43(2):1 73-205.

Rudini, Oddyana. 1988. Peranan PKK dalam Peningkatan Kedudukan dan Peranan Wanita dalam Pembangunan. Temu Karya dengan Wartawan Pengelola Media Massa dan Penulis tentang Pemasyarakatan Citra Wanita Indonesia. Peningkatan Perananya dalam Pembangunan, 1 2-13 Desember 1988, Jakarta.

Schulte Nordholt, Nico. 1987. From LSD to LKMD: Participation at the Village Level. In Local Leadership and Programme Implementation in Indonesia, Philip Quarles van Ufford, ed. Pp. 47-64. Amsterdam: Free University Press. 
Scott, Joan and Louise Tilly. 1975. Women's Work and the Family in the NineteenthCentury Europe. In The Family in History. Charles Rosenberg, ed. Philadelphia: University of Pennsylvania Press.

Shiraishi, Takaishi. 2004. The Rise of New Urban Middle Classes in Southeast Asia. Discussion paper from Research Institute of Economy, Trade and Industry. Electronic document, http://econpapers.repec.org/, accessed January 4, 2005.

Steinmetz, G., ed. 1999. State/Culture: State Formation after the cultural Turn. Ithaca: Cornell University Press.

Stoler, Ann Laura. 1977. Class Structure and Female Autonomy in Rural Java. Signs 3(1):74-89.

Sullivan, John. 1980. Back Alley Neighborhood: Kampung as Urban Community in Yogyakarta. Monash University Papers on Southeast Asia, No. 18.

1986. Kampung and State: The Role of Government in the Development of Urban Community in Yogyakarta. Indonesia 41 (April):63-88.

1992. Local Government and Community in Java: An Urban Case Study. Singapore: Oxford University Press.

Sullivan, Norma. 1983. Indonesian Women in Development: State Theory and Urban Kampung Practice. In Women's Work and Women's Roles: Economics and Everyday Life in Indonesia, Malaysia, and Singapore, Lenore Manderson, ed. Pp. 147-1 72. Development Studies Centre, Monograph No. 32. Canberra: Australian National University.

1994. Masters and Managers: A Study in Gender Relations in Urban Java. NSW, Australia: Allen and Unwin.

Suryakusuma, Julia. 1991. State Ibuism: The Social Construction of Womanhood in the Indonesian New Order. New Asian Visions 6(2): $46-71$.

1996. The State and Sexuality in New Order Indonesia. In Fantasizing the Feminine in Indonesia, Laurie Sears, ed. Pp. 92-199. Durham: Duke University Press.

Törnquist, Olle. 2002. Popular Development and Democracy: Case studies with Rural Dimensions in the Philippines, Indonesia, and Kerala. Centre for Development and the Environment, University of Oslo (in cooperation with UNRISD), Occasional Papers from SUM, No. 3.

Tsing, Anna Lownhaupt. 1993. In the Realm of the Diamond Queen: Marginality in an Out-of-the-Way Place. Princeton: Princeton University Press.

Vreede-de-Steurs, Cora. 196o. The Indonesian Woman: Struggles and Achievements. The Hague: Mouton and Company.

White, Ben. 1983. 'Agricultural Involution' and Its Critics: Twenty Years On. Bulletin of Concerned Asian Scholars 15(2):18-31.

Wieringa, Saskia. 1988. Aborted Feminism in Indonesia: A History of Indonesian Socialist Feminism. In Women's Struggles and Strategies. S. Wieringa. ed. Pp. Aldershot, UK: Gower.

- 1993. Two Indonesian Women's Organizations: Gerwani and PKK. Bulletin of Concerned Asian Scholars 25(2).

Williams, Raymond. 1961. The Long Revolution. New York: Columbia University Press. 1977. Marxism and Literature. Oxford: Oxford University Press.

Wolf, Diane. 1992. Factory Daughters: Gender, Household Dynamics, and Rural Industrialization in Java. Berkeley: University of California Press.

Wolf, Eric. 1957. Closed Corporate Communities in Mesoamerica and Java. Southwestern Journal of Anthropology 13:1-48.

1986. The Vicissitudes of the Closed Corporate Peasant Community. American Ethnologist 13:325-329.

Wolf, Margery. 1972. Women and the Family in Rural Taiwan. Stanford: Stanford University Press.

Woodward, Mark. 1989. Islam in Java: Normative Piety and Mysticism in the Sultanate of Yogyakarta. Tucson: University of Arizona Press. 
